\title{
Can Company Characteristics and Google Search Increase Stock Returns? An Evidence from Jakarta Islamic Index
}

\author{
Sri Lestari ${ }^{1}$, Retno Kurniasih ${ }^{2, *}$, Triya Aprillia Sutrisno ${ }^{3}$ \\ ${ }^{1,2,3}$ Department of Management, Faculty of Economics and Business, Universitas Jenderal Soedirman, Indonesia \\ *Corresponding author. Email: retno.kurniasih@unsoed.ac.id
}

\begin{abstract}
Stock return is the level of profit obtained by investors from the results of investment decisions in stocks. Stock returns are influenced by various types of factors, both internal and external to the company. This study uses the characteristics of the company or the company's internal factors, including company size, profitability, leverage, and liquidity. The company's characteristics are used to analyze the ability to manage the company's assets and liabilities and their effect on stock returns. This study also analyzes investors' attention, which indicates the number of searches for the company's ticker symbol on the Google Search engine. This study is a quantitative study on companies listed on the Jakarta Islamic Index. The sample is determined using the purposive sampling technique and then a sample of ten companies that fit the criteria are obtained. Panel data regression is used to analyze the effect of company characteristics and Google search on stock returns. The results showed that company size, profitability, and company liquidity positively affected stock returns. Meanwhile, leverage and Google search do not affect the company's stock returns.
\end{abstract}

Keywords: Stock Return, Company Characteristics, Google Search Volume

\section{INTRODUCTION}

Return is one of the reasons for investors to invest. Investments are usually made over a certain period to make a profit. Increasing stock returns caused by the increase in company profits indicate that the company's health level is also growing. The increase in stock returns can attract investors to invest in the company. On the other hand, a decrease in a company's stock returns indicates decreased company performance. This results in investors not wanting to invest in the company.

Stock returns are influenced by various factors, both internal and external factors of the company. External factors are the form of macroeconomic and non-economic factors [1]. Macroeconomic factors may include inflation, interest rates, exchange rates, economic growth rates, and others. Non-economic macro factors may include domestic political events, international political events, social events, legal events, and so on. Factors originating from the internal of the company are described in the company's financial statements. Previous researchers produced different findings of the effect of these various factors on stock returns.

Sharpe (1964) proposed the CAPM theory, which states that the only factor influencing stock returns is systematic risk, also known as beta. Beta, or systematic risk, is the risk that is inherent in the entire market. The Fama and French Three-Factor Model (The Fama and French Three-Factor Model) extends the capital asset pricing model (CAPM) by adding size risk and value risk factors to market risk factors in the CAPM [3].

The three-factor model developed by Fama and French is intended to capture the relationship between average return and company characteristics, in this case, size and book-tomarket ratio [3]. Fama and French further proposed a fivefactor model by adding profitability and investment factors to the three-factor model. The document shows a pattern in average returns related to size, book-to-market, profitability, and investment patterns [4].

Nguyen et al. (2019) developed the Fama and French (2015) model that explains stock returns by adding leverage factors in company characteristics, macroeconomic factors, and using investor attention to explain the company's investment activities. The effect of macroeconomics, company characteristics, and investor attention on stock returns is different in each country [5].

The characteristics of the company are generally unique characteristics inherent in a company. Several indicators that mark a company and distinguish it from other companies are the company characteristics. There are six categories of company characteristics: value-versus-growth, investment patterns, profitability, momentum, trade frictions, and intangibles [6].

Another factor that can affect stock returns is investment patterns [4]. In terms of investment decisions, investors must be selective in processing information due to the amount of 
information available. Quickly getting new information requires the careful attention of investors in processing and considering the information used in their decision-making.

Investor attention was used by Nguyen et al. (2019) as an indicator of investment patterns. Investors' attention can be used to process information and incorporate its knowledge into their decisions. Stock prices can be reflected by important news or information if investors pay attention to them. Several studies have shown that investors' attention can play an essential role in determining asset prices, affecting returns.

Based on the description that has been submitted, many factors affect stock returns, both from internal and external factors of the company. This study will examine factors that come from the company's internal. Internal factors can be said to be characteristics of the company because they are inherent in a company. The characteristics of the company to be studied include company size, profitability, leverage, and liquidity. The company's four characteristics are all related to how it manages its assets and liabilities. This study examines the effect of the company's asset and liability management performance on the stock returns received by investors. To know the performance of a company, investors must have information related to the company. Therefore, this study also examines investor attention as an indicator of investment patterns.

Existing measures of investor's concerns may include turnover, extreme returns, news, and advertising. Mondria et al. (2010) measured the attention of United States investors using internet search query data or search engine tools data, and the results showed significantly. Search engines are a standard tool for assisting users in finding trustworthy information [7]. This tool is used due to the shorter time required to obtain information. The research of Mondria et al. (2010) was developed by Da et al. (2011) by using Google Search Volume (GSV). The search volumes reported by Google tend to reflect the general public's internet search behavior. It was found that an increase in GSV using the company ticker symbol would predict an increase in the stock price [8].

When conducting research, picking the correct Google search keyword is crucial. Users must distinguish companies from similar words, related companies, or trademarks using a search that is limited enough. Da et al. (2011) used stock ticker symbols as keywords in their study. A stock ticker symbol is an array of characters used to uniquely identify a stock listed on an exchange or publicly traded. When a company issues securities to the public market, it selects the ticker symbols available for its securities that investors and traders use to transact.

\section{LITERATURE REVIEW AND HYPOTHESES DEVELOPMENT}

\subsection{Literature Review}

The Fama and French Three-Factor Model (The Fama and French Three-Factor Model) is an asset pricing model developed in 1992. The results of research by Fama and French (1992) found that the book-to-market ratio and the size ratio influence the average stock return on the New York Stock Exchange (NYSE).

Fama and French (2015) made developments in their research. By proposing a five-factor model by incorporating the profitability and investment factors into the three-factor model. The five-factor model aimed at capturing size, value, profitability, and investment patterns in average stock return, performed better than the three-factor model.

\subsubsection{Company Size}

A company is a legal entity established by two or more people who are members of a group to operate a business entity with commercial or industrial capabilities. Companies can be public or private. Some companies issue equity to shareholders on the stock exchange, and some companies are privately owned and unregulated.

Several indicators can show a condition or company characteristics, one of which is the company's size. Total assets, total sales, total profits, and tax expenses can indicate the size of a company [9] .

\subsubsection{Profitability}

Profit is the total income or income excluding costs or expenses incurred by the company. Make a profit is always the company's goal. Profitability is closely related to profit. While profit is an absolute number, profitability is a relative thing.

The profitability ratios combine the implications of liquidity, asset management, and debt on operating results [9]. Profitability is the company's ability to generate income that is greater than its expenses.

\subsubsection{Leverage}

Debt is an obligation that must be paid. Various kinds of needs needed by the company can be financed by debt. If the use of debt is maximized and supported by effective management, debt will make the company achieve its productivity. To find out how effective the use of debt is, we can know by the leverage ratio. The leverage ratio is the ratio used to capture how far debt finances the company's assets [10]. 


\subsubsection{Liquidity}

Liquid assets can be converted quickly into cash without having to shrink the price of the asset [9]. Liquidity refers to the ease with which an asset or security can convert into cash without affecting its market price. In short, liquidity describes an asset that can be bought or sold in the market quickly. Cash is generally considered the most liquid asset because it can be converted easily and quickly into other assets.

\subsubsection{Investor's Attention}

Attention in investing is reflected by attention to information. The information is then interpreted for decision-making. The concept of "recognition of investors" was introduced by Merton in 1987 and suggests that investors' attention may be relevant to market activity. Merton examines the investment behavior of each firm and the firm's role in determining the size of its investor base [11].

Mondria et al. (2010) measured the attention of United States investors using internet search query data or search engine tools data and the measurement showed a significant result. Search engines are a popular tool to help users find reliable information because the time required is shorter to obtain the information.

\subsection{Hypotheses Development}

\subsubsection{The Effect of Company Size on Stock Returns}

Size in the three-factor model of Fama and French (1992) has a significant negative relationship to stock returns. Companies that have a small size generate higher returns than large companies. Investors are also easier to monitor and follow the development of small companies. Large companies require more funds or capital than small companies.

Duy and Huu Phuoc (2016) found that company size had a negative effect on stock returns. In other words, small companies can provide higher stock returns.

\section{H1: Company Size has a Negative Effect on Stock Return}

\subsubsection{The Effect of Profitability on Stock Returns}

Profitability shows the company's performance in generating profits. Profitability in the five-factor model of Fama and French (2015) has a positive relationship to return. Companies with a high level of profitability have greater returns than the stock returns of companies that have a low level of profitability.

Return on Assets (ROA) is one of the financial ratios related to company profitability. Return on assets has a positive and significant effect on the stock return [13].

\subsubsection{The Effect of Leverage on Stock Returns}

Financial leverage refers to the amount of debt in the company's account. The Debt-to-Asset Ratio (DR) is a leverage ratio that shows the percentage of assets financed by debt. The ratio of debt-to-assets is critical in determining the financial risk of a company. A ratio value greater than one indicates that most assets are funded with debt and the company has a higher risk of default.

The debt to assets ratio in Prasetyo (2013) research has a negative effect on stock prices in manufacturing companies listed on the IDX for 2009-2011. It can be interpreted that the higher the value of the debt-to-assets ratio, the lower the company's stock price.

H3: Leverage has a Negative Effect on Stock Returns.

\subsubsection{The Effect of Liquidity on Stock Returns}

Liquidity is an indicator that shows the company's capability to pay off short-term financial obligations promptly using current assets owned by the company [15]. One of the ratios often used to analyze a company's liquidity ratio is the Current Ratio (CR). The current ratio indicates the company's performance in paying off its short-term obligations and operational activities. If operational activities can be financed appropriately, the company will benefit and attract investors to invest in the company.

Research conducted by Jabbari and Fathi (2014) shows a positive effect of the current ratio on stock returns. It shows that an increase in the current ratio is followed by an increase in stock return. Conversely, if there is a decrease in the current ratio, it will also be followed by a decrease in stock returns.

H4: Liquidity has a Positive Effect on Stock Returns.

\subsubsection{The Effect of Google Search on Stock Returns}

Investors have unlimited cognitive resources or beliefs with a high level of attention to stock market activities. Merton (1987) states that investors will only invest with companies they know. Searching for information through search engines like Google is often done by many people, including investors. Investors collect information related to a company if they are interested in a company.

The measurement of the attention of US investors was carried out by Mondria et al. (2010) using internet search query data or search engine tools data and the results shown are significant. Google Search Volume (GSV) was utilized by Da et al. (2011) to directly measure investor interest. An increase in GSV using the ticker symbol of the company's stock will predict an increase in share price [8].

H5: Google Search Volume Has a Positive Effect on Stock Returns.

H2: Profitability has a Positive Effect on Stock Returns 


\section{METHODS}

Based on the data analysis, this research includes the type of quantitative research. Researchers collect data that each company has reported. The object of this research is company size, profitability, leverage, liquidity, and Google search volume and their effect on stock returns.

The non-probability sampling technique with the purposive sampling technique was employed in this research. Purposive sampling is a technique for selecting samples based on pre-determined criteria. The criteria applied for the study were companies listed on the Jakarta Islamic Index (JII) consecutively from the period 2013-2019.

Table 1. Definition of Conceptual and Operational Variables

\begin{tabular}{|c|c|c|}
\hline Variable & Description & Equation \\
\hline $\begin{array}{l}\text { Stock } \\
\text { Return }\end{array}$ & $\begin{array}{l}\text { Stock return is the rate of } \\
\text { return or profit received by } \\
\text { investors from the results } \\
\text { of investments made. }\end{array}$ & $R_{i t}=\frac{P_{i t}-P_{i t-1}}{P_{i t-1}}$ \\
\hline Size & $\begin{array}{l}\text { Total assets represent the } \\
\text { company's size; the more } \\
\text { the total assets possessed } \\
\text { by the company, the larger } \\
\text { the company. }\end{array}$ & $\begin{array}{l}\text { Size } \\
\qquad=\operatorname{Ln}\left(\begin{array}{c}\text { Total } \\
\text { Asset }\end{array}\right)\end{array}$ \\
\hline Profitability & $\begin{array}{l}\text { Return on assets can } \\
\text { describe the company's } \\
\text { success in generating } \\
\text { profits [9]. }\end{array}$ & $\begin{array}{l}\mathrm{ROA}= \\
\frac{\mathrm{EAT}}{\text { Total Asset }}\end{array}$ \\
\hline Leverage & $\begin{array}{l}\text { Leverage shows how far } \\
\text { the company's assets are } \\
\text { financed with debt [10]. }\end{array}$ & $\begin{array}{l}\text { DR }= \\
\frac{\text { Total Debts }}{\text { Total Asset }}\end{array}$ \\
\hline Liquidity & $\begin{array}{l}\text { Liquidity shows its } \\
\text { capability to promptly pay } \\
\text { its short-term debt using its } \\
\text { current assets [15]. }\end{array}$ & $\begin{array}{l}\mathrm{CR}= \\
\text { Current Asset } \\
\text { Current Liabilities }\end{array}$ \\
\hline $\begin{array}{l}\text { Google } \\
\text { Search } \\
\text { Volume }\end{array}$ & $\begin{array}{l}\text { To normalize the data, the } \\
\text { total number of Google } \\
\text { searches for each ticker } \\
\text { symbol was converted into } \\
\text { logarithms [5]. }\end{array}$ & $\begin{array}{l}\text { GSV }= \\
\log \left(\begin{array}{c}\text { Google } \\
\text { Search } \\
\text { Volume }\end{array}\right)\end{array}$ \\
\hline
\end{tabular}

The regression model estimation method using panel data can be done through three approaches, namely Common Effect Model (CEM), Fixed Effect Model (FEM), and Random Effect Model (REM). The panel data regression estimation model method is determined to be used by performing the Chow Test and Hausman Test [17].

\section{RESULT AND DISCUSSION}

\subsection{Estimation Model Selection}

\subsubsection{Chow Test}

Table 2. Result of Chow Test

\begin{tabular}{|l|r|r|r|}
\hline \multicolumn{1}{|c|}{ Effects Test } & Statistic & d.f. & Prob. \\
\hline Cross-section F & 2.186006 & $(9,259)$ & 0.0234 \\
\hline Cross-section Chi-square & 20.060847 & 9 & 0.0175 \\
\hline
\end{tabular}

Based on the results of the Chow test that tested the expected effect and fixed effect, the probability value of the cross-section $\mathrm{F}$ was 0.0234 . This probability value is smaller than (0.05). Statistically, H0 is not accepted, and $\mathrm{Ha}$ is accepted $(0.0234<0.05)$. So, the correct model used is the fixed effect model.

\subsubsection{Hausman Test}

Table 3. Result of Hausman Test

\begin{tabular}{|c|c|c|c|}
\hline Test Summary & Chi-Sq. Statistic & Chi-Sq. d.f. & Prob. \\
\hline Cross-section random & 17.551300 & 5 & 0.0036 \\
\hline
\end{tabular}

Based on the results of the Hausman test, which tested between random effects and fixed effects, the probability value was 0.0036 . The probability value is smaller than (0.05). Statistically, H0 is not accepted, and Ha is accepted $(0.0036<0.05)$, so the correct model is the fixed effect model.

\subsection{Classic Assumption Test}

\subsubsection{Multicollinearity Test}

Table 4. Result of Multicollinearity Test

\begin{tabular}{|c|c|c|c|c|c|}
\hline & SIZE & ROA & DR & CR & GSV \\
\hline SIZE & 1.000000 & -0.285909 & 0.065596 & -0.300281 & -0.421353 \\
\hline ROA & -0.285909 & 1.000000 & 0.116799 & -0.220639 & 0.061758 \\
\hline DR & 0.065596 & 0.116799 & 1.000000 & -0.811124 & -0.153005 \\
\hline CR & -0.300281 & -0.220639 & -0.811124 & 1.000000 & 0.343590 \\
\hline GSV & -0.421353 & 0.061758 & -0.153005 & 0.343590 & 1.000000 \\
\hline
\end{tabular}

Based on the correlation matrix output results in table 4, there is no correlation between the independent variables that are high above 0.80 . So, it can be concluded that there is no multicollinearity between independent variables. 


\subsubsection{Heteroscedasticity Test}

Table 5. Result of Heteroscedasticity Test

\begin{tabular}{|l|r|r|r|r|}
\hline Variable & \multicolumn{1}{|c|}{ Coefficient } & \multicolumn{1}{|c|}{ Std. Error } & \multicolumn{1}{c|}{-Statistic } & \multicolumn{1}{c|}{ Prob. } \\
\hline C & 1.483847 & 0.747497 & 1.985087 & 0.0482 \\
\hline SIZE & -0.043054 & 0.023368 & -1.842447 & 0.0666 \\
\hline ROA & -0.013772 & 0.026952 & -0.510978 & 0.6098 \\
\hline DR & -0.001194 & 0.001074 & -1.111906 & 0.2672 \\
\hline CR & 0.030461 & 0.042232 & 0.721269 & 0.4714 \\
\hline GSV & 0.043278 & 0.024555 & 1.762483 & 0.0792 \\
\hline
\end{tabular}

Based on the regression output between the residuals and the independent variables, there is no significant relationship between all independent variables on the absolute residual value. So, it can be concluded that the non-heteroscedasticity assumption is met.

\subsection{Panel Data Regression}

Panel data regression in this study uses a fixed-effect model. The selection of the fixed-effect model as a method of analyzing panel data in this study was previously tested through the Chow test and the Hausman test.

Table 6. Result of Fixed Effect Model

\begin{tabular}{|l|r|r|r|r|}
\hline Variable & Coefficient & Std. Error & t-Statistic & Prob. \\
\hline C & 2.774970 & 1.237143 & 2.243048 & 0.0257 \\
\hline SIZE & -0.099270 & 0.038675 & -2.566773 & 0.0108 \\
\hline ROA & 0.149834 & 0.044607 & 3.358978 & 0.0009 \\
\hline DR & 0.001441 & 0.001777 & 0.811023 & 0.4181 \\
\hline CR & 0.184368 & 0.069896 & 2.637735 & 0.0089 \\
\hline GSV & -0.008254 & 0.040640 & -0.203110 & 0.8392 \\
\hline
\end{tabular}

Fixed Effects (Cross)

\begin{tabular}{|l|l|l|l|}
\hline ADRO-C & 0.079646 & INDF-C & 0.106036 \\
\hline AKRA - C & -0.068101 & KLBF-C & -0.220535 \\
\hline ASII-C & 0.196455 & TLKM-C & 0.158037 \\
\hline BSDE-C & -0.081432 & UNTR - C & 0.037376 \\
\hline ICBP-C & -0.058958 & UNVR-C & -0.127850 \\
\hline
\end{tabular}

\begin{tabular}{|l|r|}
\hline Adjusted R-squared & 0.060270 \\
\hline Prob(F-statistic) & 0.006691 \\
\hline
\end{tabular}

\begin{tabular}{|l|r|}
\hline Prob(F-statistic) & 0.006691 \\
\hline
\end{tabular}

The fixed effect estimation model is as follows:

$$
\begin{aligned}
\text { RETURN }_{i t}= & 2.774970-0.068101 D_{2 i}-0.196455 D_{3 i}- \\
& 0.081432 D_{4 i}-0.058958 D_{5 i}-0.106036 D_{6 i}- \\
& 0.220535 D_{7 i}+0.037376 D_{8 i}+0.037376 D_{9 i}- \\
& 0.099270 \mathrm{SIZE}_{i t}+0.149834 \mathrm{ROA}_{i t}+ \\
& 0.001441 \mathrm{DR}_{i t}+0.184368 \mathrm{CR}_{i t}-0.008254 \\
& \mathrm{GSV}_{i t}+u_{i t}
\end{aligned}
$$

Based on the results of panel data regression (Table 6), the the Adjusted R-square value is 0.060270 . It means that, taken together, size, DR, CR, ROA, and GSV only influence return of 0.060270 or $6.027 \%$ and the rest $(93.973 \%)$ is influenced by other factors not examined.

Based on the results of panel data regression (Table 6), the probability value is $0.006691<(0.05)$, then $\mathrm{H} 0$ is not accepted and $\mathrm{Ha}$ is accepted. It shows the effect of size, ROA, DR, CR, and GSV concurrently on stock returns.

Table 7. Acceptance of The Hypothesis of The Influence of Independent Variables on Stock Returns

\begin{tabular}{|c|l|c|c|}
\hline & \multicolumn{1}{|c|}{ Hypothesis Statement } & $\begin{array}{c}P_{-} \\
\text {value }\end{array}$ & $\begin{array}{c}\text { Informati } \\
\text { on }\end{array}$ \\
\hline H1 & $\begin{array}{l}\text { Firm size has a negative } \\
\text { effect on stock returns }\end{array}$ & 0.0108 & Accepted \\
\hline H2 & $\begin{array}{l}\text { Return on assets has a } \\
\text { positive effect on stock } \\
\text { returns }\end{array}$ & 0.0009 & Accepted \\
\hline H3 & $\begin{array}{l}\text { The debt-to-assets ratio has } \\
\text { a negative effect on stock } \\
\text { returns }\end{array}$ & 0.4181 & $\begin{array}{c}\text { Not } \\
\text { accepted }\end{array}$ \\
\hline H4 & $\begin{array}{l}\text { The current ratio has a } \\
\text { positive effect on stock } \\
\text { returns }\end{array}$ & 0.0089 & Accepted \\
\hline H5 & $\begin{array}{l}\text { Google search has a positive } \\
\text { effect on stock returns }\end{array}$ & 0.8392 & $\begin{array}{c}\text { Not } \\
\text { accepted }\end{array}$ \\
\hline
\end{tabular}

\subsection{Discussion}

\subsubsection{The Effect of Company Size on Stock Returns}

In this study, the company's size is described by the total assets, both current and non-current assets owned by the company. The coefficient of the variable size or firm size has a value of -0.099270 and t-statistic -2.566773 with a probability of 0.0108 , so there is a negative and significant effect of firm size on stock returns.

In Fama and French's three-factor model, the company's size has a significant negative relationship with stock returns [3]. Small companies generate higher returns than large companies and vice versa. Capital can come from debt which has an impact on the amount of profit of a company. This results in profits that cannot be obtained optimally by investors because they must pay off existing debts.

\subsubsection{The Effect of Profitability on Stock Returns}

This study uses Return on Assets (ROA) to describe the profitability of a company. The ROA variable coefficient has a value of 0.149834 and a t-statistic of 3.358978 with a probability of 0.0009 . So, ROA has a positive and significant effect on stock returns.

In the five-factor model of Fama and French (2015), profitability has a positive relationship to return. Profitability, as described by Return-on-Assets (ROA), can measure the 
company's ability to generate profits at the income level. The increasing value of the ROA ratio indicates that the company's net income also increases.

\subsubsection{The Effect of Leverage on Stock Returns}

Debt-to-Asset Ratio (DR) is used in this study to describe the company's financial leverage. The coefficient of the DR variable has a value of 0.001441 and a t-statistic of 0.811023 with a probability of 0.4181 . So, the effect of DR on stock returns is not significant or can be said not to affect.

Leverage described by the debt-to-asset ratio (DR) is a measure that shows the size of the company's assets financed by debt rather than equity. One of the drawbacks of the debtto-asset ratio is that it does not indicate asset quality because it combines all tangible and intangible assets into one. The debt-to-asset ratio must always be evaluated from time to time to assess whether the company's financial risk is improving or deteriorating.

\subsubsection{The Effect of Liquidity on Stock Returns}

This study uses the current ratio (CR) to describe the company's liquidity. The coefficient of $\mathrm{CR}$ variable has a value of 0.184368 and a t-statistic of 2.637735 with a probability of 0.0089 . So, CR has a positive and significant effect on stock returns. Jabbari and Fathi (2014) also agree with the finding.

Liquidity described by the current ratio (CR) shows the level of the company's ability to pay short-term obligations and operational activities. High liquidity value can be obtained by optimally managing assets and liabilities. The company is considering paying off its short-term obligations if the liquidity value is high.

\subsubsection{The Effect of Google Search on Stock Returns}

In this study, investors' attention is depicted by the Google Search Volume (GSV) ticker symbol of a company. The coefficient of the GSV variable has a value of 0.008254 and t-statistic $-0,203110$ with a probability of 0.8392. So, GSV does not affect stock returns.

In this study, investors' attention is depicted by the company's ticker symbol in Google Search. Google is a popular search engine for finding credible information because of the time necessary to access the information. However, Google results cover a wide range of topics.

\section{CONCLUSION}

This study aims to analyze the effect of company characteristics and Google search on stock returns. This research was conducted on companies listed on the Jakarta Islamic Index (JII) for 2013-2019.

Based on the results and discussions in this study, the following conclusions were obtained:
1) Company size has a negative effect on stock returns

2) Profitability has a positive effect on stock returns

3) Leverage does not affect stock returns

4) Liquidity has a positive effect on stock returns

5) Google search does not affect stock returns

\section{REFERENCES}

[1] M. Samsul, Pasar Modal dan Manajemen Portofolio. Jakarta: Erlangga, 2008.

[2] W. F. Sharpe, "Capital Asset Prices: a Theory of Market Equilibrium Under Conditions of Risk," J. Finance, vol. 19, no. 3, pp. 425-442, 1964, doi: 10.1111/j.15406261.1964.tb02865.x.

[3] E. F. Fama and K. R. French, "The Cross-Section of Expected Stock Returns," J. Finance, vol. 47, no. 2, pp. 427465, Jun. 1992, doi: 10.1111/j.1540-6261.1992.tb04398.x.

[4] E. F. Fama and K. R. French, "A five-factor asset pricing model," J. financ. econ., vol. 116, no. 1, pp. 1-22, Apr. 2015, doi: 10.1016/j.jfineco.2014.10.010.

[5] C. P. Nguyen, C. Schinckus, and T. V. Hong Nguyen, "Google search and stock returns in emerging markets," Borsa Istanbul Rev., vol. 19, no. 4, pp. 288-296, 2019, doi: 10.1016/j.bir.2019.07.001.

[6] F. Jiang, G. Tang, and G. Zhou, "Firm Characteristics and Chinese Stocks," J. Manag. Sci. Eng., vol. 3, no. 4, pp. 259283, 2019, doi: 10.3724/SP.J.1383.304014.

[7] J. Mondria, T. Wu, and Y. Zhang, "The determinants of international investment and attention allocation: Using internet search query data," J. Int. Econ., vol. 82, no. 1, pp. 85-95, 2010, doi: 10.1016/j.jinteco.2010.04.007.

[8] Z. Da, J. Engelberg, and P. Gao, "In Search of Attention," J. Finance, 2011, doi: 10.1111/j.1540-6261.2011.01679.x.

[9] E. F. Brigham and J. F. Houston, Dasar-Dasar Manajemen Keuangan, 11th ed. Jakarta: Salemba Empat, 2010.

[10] Kasmir, Analisis Laporan Keuangan. Jakarta: PT Raja Grafindo Persada, 2012.

[11] R. C. Merton, "A Simple Model of Capital Market Equilibrium with Incomplete Information," J. Finance, vol. 42, no. 3, pp. 483-510, 1987, doi: 10.1111/j.15406261.1987.tb04565.x

[12] N. T. Duy and N. P. Huu Phuoc, "The Relationship between Firm Sizes and Stock Returns of Service Sector in Ho Chi Minh City Stock Exchange," Rev. Eur. Stud., vol. 8, no. 4, p. 210, 2016, doi: 10.5539/res.v8n4p210.

[13] M. A. M. Kabajeh, S. M. A. AL Nu'aimat, and F. N. Dahmash, "The Relationship between the ROA, ROE and ROI Ratios with Jordanian Insurance Public Companies Market Share Prices," Int. J. Humanit. Soc. Sci., vol. 2, no. 1, 2012.

[14] A. Prasetyo, "Pengaruh Leverage dan Profitabilitas Terhadap Harga Saham Pada Perusahaan Manufaktur Yang Terdaftar di Bursa Efek Indonesia Tahun 2009-2011,” J. Econ., vol. 2, pp. 1-20, 2013.

[15] L. Syamsudin, Manajemen Keuangan Perusahaan. Jakarta: PT Raja Grafindo Persada, 2011.

[16] E. Jabbari and Z. Fathi, "Prediction of Stock Returns Using Financial Ratios Based on Historical Cost , Compared With Adjusted Prices ( Accounting for Inflation ) With Neural," Indian J. Fundam. Appl. Life Sci., vol. 4, no. 2003, pp. 1064 1078, 2014.

[17] I. Ghozali and D. Ratmono, Analisis Multivariat dan Ekonometrika dengan Eviews 10. Semarang: Badan Penerbit Universitas Diponegoro, 2017. 